Amir Ghorbanpour, Aliyeh K. Z. Kambuziya, Mohammad Dabir-Moghaddam \& Ferdows Agha-Golzadeh 95

Journal of Universal Language 20-2. September 2019, 95-127

DOI 10.22425/jul.2019.20.2.95

eISSN 2508-5344

\title{
Loanword Syllable Adaptation in Persian: An Optimality-Theoretic Account
}

\author{
Amir Ghorbanpour*, Aliyeh K. Z. Kambuziya*, \\ Mohammad Dabir-Moghaddam ${ }^{* *}$ \& \\ Ferdows Agha-Golzadeh*
}

Tarbiat Modares University*, Allameh Tabataba'i University**, Iran

\author{
$\S$ This paper is taken from the first author's Ph.D. dissertation. \\ Amir Ghorbanpour (First \& Corresponding author) \\ Ph.D. Graduate, Tarbiat Modares University, Tehran, Iran \\ Email: amir.ghorbanpour@modares.ac.ir \\ Aliyeh K. Z. Kambuziya (Co-author) \\ Associate Professor, Tarbiat Modares University, Tehran, Iran \\ Email: akord@modares.ac.ir \\ Mohammad Dabir-Moghaddam (Co-author) \\ Professor, Allameh Tabataba'i University, Tehran, Iran \\ Email: dabirmoghaddam@atu.ac.ir \\ Ferdows Agha-Golzadeh (Co-author) \\ Professor, Tarbiat Modares University, Tehran, Iran \\ Email: aghagolz@modares.ac.ir
}

Received 5 July, 2019; Revised 2 September, 2019; Accepted 16 September, 2019

Copyright (C) 2019 Language Research Institute, Sejong University Journal of Universal Language is an Open Access Journal. All articles are distributed online under the terms of the Creative Commons Attribution Non-Commercial License

(http://creativecommons.org/licenses/by-nc/3.0) which permits unrestricted non-commercial use, distribution, and reproduction in any medium, provided the original work is properly cited. 


\begin{abstract}
The present paper examines the process of loanword syllable adaptation in tetrasyllabic words in Persian, within an Optimalitytheoretic framework. In Persian, consonant clusters are avoided in onset position. As a result, the loanwords borrowed from other languages which have complex onsets, when introduced into Persian, are adapted to fit the syllable structure of the target language. When placed word-initially, the onset cluster is generally resolved by the insertion of an epenthetic vowel. However, this vowel epenthesis occurs in a split pattern, as it does in many other languages. In this study, following Gouskova's (2001) proposal, we argue that this split pattern in loanword syllabic adaptation can best be explained to be an effect of the Syllable Contact Law (SCL). That is, when the two segments in the onset cluster have a rising sonority sequence, the cluster is broken up by the process of anaptyxis; while in sequences of falling sonority, the cluster is resolved through the process of prothesis. It is argued that, this pattern uniformly holds true at least as far as the dictionary-derived data in the present study are concerned. For the exceptional cases of /SN/ and /SL/ clustersnot attested in our data set, but still present and frequently referred to in the literature - we propose the addition of two positional faithfulness constraints of the DEP-V/X_Y family (Fleischhacker 2001) to our set of universal constraints to account for all the possible cases of loanword syllabic adaptation in Persian.
\end{abstract}

Keywords: loanword, syllable, adaptation, consonant cluster, optimality theory (OT), Persian phonology

\title{
1. Introduction
}

In Persian, consonant clusters are generally avoided in onset position. That is, the syllable structure of Persian does not allow complex onsets in the phonetic realisation of the words. As a result, the loanwords borrowed from other languages which have complex onsets, when 
Amir Ghorbanpour, Aliyeh K. Z. Kambuziya, Mohammad Dabir-Moghaddam \& Ferdows Agha-Golzadeh 97

introduced into Persian, are adapted to fit the syllable structure of the target language. When placed word-medially subsequent to an open syllable, this syllabic adaptation usually takes place by resolving the cluster without an epenthesis; that is, the first segment of the cluster moves to the empty coda position of the preceding syllable, as is the case in the following examples:

(1) Onset cluster resolution: re-syllabification without epenthesis [de.moc.ra.si] 'democracy' [bu.roc.ra.si] 'bureaucracy' [bi.jof.ra.fi] 'biography' [te.leJ.ra.fi] 'telegraphic'

When placed word-initially, however, the onset cluster is resolved by the insertion of an epenthetic vowel to break up the cluster. However, this vowel epenthesis occurs in a split pattern, as it does in many other languages (Fleischhacker 2001, Gouskova 2001). That is, in some loanwords, the epenthetic vowel is inserted between the two consonants to break up the cluster, as is the case with the examples in (2) below-a process known as anaptyxis in the literature (Crystal 2008: 25-26); while, in some other loanwords, namely those beginning with /s/-initial clusters, the consonant cluster is not broken up and there is no word-internal epenthesis. Rather, in this latter group of loanwords, to avoid complex onsets, a vowel is added to the beginning of the word to resolve the cluster-a process known as prothesis in the literature (ibid.: 394) - , as is the case in the examples in (3) below. 
(2) Onset cluster resolution: anaptyxis

$\begin{array}{llll}\text { [te.ra.ze.di] } & \text { 'tragedy' } & \text { [pe.re.zi.dent] } & \text { 'president' } \\ \text { [te.ran.zis.tor] } & \text { 'transistor' } & \text { [po.ro.te.Pin] } & \text { 'protein' } \\ \text { [de.ra.ma.tic] } & \text { 'dramatic' } & \text { [po.ro.fe.sor] } & \text { 'professor' } \\ \text { [je.ra.ma.fon] } & \text { 'gramophone' } & \text { [po.ro.to.kol] } & \text { 'protocol' } \\ \text { [pe.las.ti.ci] } & \text { 'plastic' } & \text { [ko.ro.ko.dil] } & \text { 'crocodile' }\end{array}$

(3) Onset cluster resolution: prothesis

[Pes.ta.di.jom] ${ }^{1} \quad$ 'stadium'

[Pes.to.di.jo] 'studio'

[Pes.pa.je.ti] 'spaghetti'

[?es.ta.lac.tit] 'stalactite'

Previous studies on various languages have offered different explanations for this split pattern of epenthesis, including, among others, the different structure of s-obstruent clusters - in that they are seen as complex segments which cannot be broken up by epenthesis (Broselow 1992); the special perceptual properties of sibilant-initial clusters (Fleischhacker 2001); and lastly, the effect of the sonority profile of the cluster (Singh 1985) and, hence, the Syllable Contact Law (SCL) on this split pattern (Gouskova 2001).

In this paper, after briefly discussing some of the previous studies and analyses of this split pattern in onset cluster resolution, we will look at the process of loanword syllabic adaptation in a set of tetrasyllabic words in Persian, and the strategies adopted by the language to modify the ill-formed structures in order to meet the

\footnotetext{
${ }^{1}$ In their phonetic realisations, all Persian syllables are considered to have an onset consonant. In cases where there is no onset in the underlying form, a glottal stop [?] is inserted. This is argued to hold true at least for the formal pronunciation of words in isolation. However, this fact does not concern our argument here and will be taken up later on in a related section on ONSET constraint.
} 
requirements imposed by its syllable structure. These strategies are studied within an Optimality-theoretic framework (Prince \& Smolensky 1993/2004, McCarthy 2008), and the aim is to examine the ranking of the relevant universal constraints on syllable structure which are active and decisive in this regard, and the way these constraints interact with one another in Persian to give the desired optimal outputs as allowed in the language.

The data under discussion in the present study provide further support for Gouskova's (2001) proposal in arguing that this split pattern in loanword syllable adaptation can best be explained to be an effect of the SYLlable CONTACT. That is, when the two segments in a cluster have a sequence of rising sonority, the cluster is broken up by anaptyxis; while in sequences of falling sonority, the cluster is resolved through prothesis. As will be discussed, this pattern uniformly holds true at least as far as the dictionary-derived data in the present study are concerned. For the special cases of /SN/ (sibilant-nasal) and /SL/ (sibilant-liquid) clusters - which are not attested in our set of data, but still present (whether as established loanwords or as nativised pronunciation of foreign words) and frequently referred to in the literature-we, following Fleischhacker (2001), will propose and add two positional, context-sensitive faithfulness constraints of the DEP-V/X_Y family to the set of universal constraints to account for all the possible cases of loanword syllabic adaptation in Persian.

\section{Background}

\subsection{Persian Sound System}

Before moving on to the discussion of the loanword adaption, a brief description of the phoneme inventory and syllable structure of 
Persian should be helpful. Beginning with the phoneme inventory of the language, the sound system of modern standard Persian consists of six simple vowels and twenty-three consonants (Samareh 1999, Kambuziya 2007, inter alia) as illustrated below in Figure 1 and Table 1 , respectively.

Figure 1. Persian Vowels Diagram

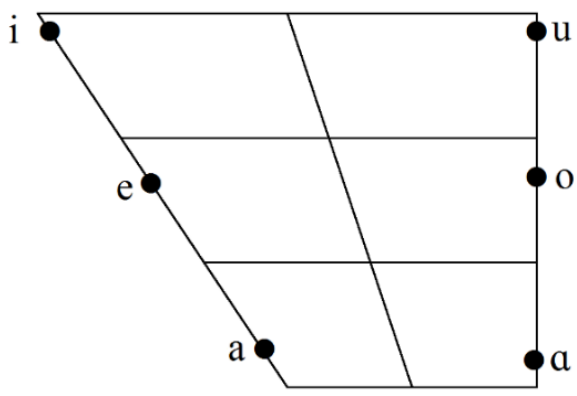

Table 1. Persian Consonant Phonemes

\begin{tabular}{|c|c|c|c|c|c|c|c|}
\hline & Bilabial & $\begin{array}{c}\text { Labio- } \\
\text { Dental }\end{array}$ & Alveolar & $\begin{array}{c}\text { Palato- } \\
\text { Alveolar }\end{array}$ & Palatal & Uvular & Glottal \\
\hline Plosive & $\mathrm{p} \mathrm{b}$ & & $\mathrm{t} \quad \mathrm{d}$ & & $\mathrm{c} \quad \mathrm{J}$ & $\mathrm{G}$ & ? \\
\hline Affricate & & & & $\mathrm{t} \int \mathrm{d} 3$ & & & \\
\hline Fricative & & $\mathrm{f} \quad \mathrm{v}$ & $\mathrm{s} \quad \mathrm{z}$ & $\int \mathrm{J}$ & & $\chi$ & $\mathrm{h}$ \\
\hline Nasal & $\mathrm{m}$ & & $\mathrm{n}$ & & & & \\
\hline Glide & & & & & $\mathrm{j}$ & & \\
\hline Lateral & & & $\mathrm{l}$ & & & & \\
\hline Trill & & & $\mathrm{r}$ & & & & \\
\hline
\end{tabular}


As can be seen in the consonants chart in Table 1, the palatal stops $/ \mathrm{c} /$ and $/ \mathrm{J} /$ are taken to be underlying phonemes in the Persian sound system, only occurring as allophones $[\mathrm{k}]$ and $[\mathrm{g}]$ before back vowels in their phonetic realisations (Kambuziya et al. 2017).

Regarding the syllabic architecture, Persian has a syllable structure of $\mathrm{CV}(\mathrm{C})(\mathrm{C})$; that is, any syllable in its surface realisation contains an obligatory onset consonant, an obligatory vowel as nucleus, and an optional coda consisting of one or two consonants (Windfuhr 1997, Haghshenas 1999: 138-139, Samareh 1999: 108-110, Kambuziya 2007, inter alia). Thus, bearing in mind that all syllables should have an obligatory onset consonant in their surface realisations, in cases where there is no onset in the underlying form, a glottal stop [?] is said to be inserted (Kambuziya 2007, Ghorbanpour et al. 2019, inter alia), as already alluded to above in a footnote. This is argued to hold true at least for the formal pronunciation of words in isolation. This fact regarding the syllable structure of Persian will be taken up again later in a related discussion on the ONSET and NO-CODA constraints.

\subsection{Split Epenthesis Pattern in Loanwords}

A number of previous studies have addressed the split pattern of vowel epenthesis in loanwords in various languages, some of which will be looked at briefly in this section, with particular focus on this pattern occurring in Persian.

Fleischhacker (2001) in a comprehensive study of the asymmetries observed in cluster-resolving epenthesis across languages, argues that in languages displaying anaptyxis-prothesis asymmetries, the epenthesis site is chosen so as to maximise auditory similarity between the nonepenthesised input and the output. In support of her proposal, Fleischhacker presents results from two experiments corroborating the major claim that for the input obstruent + sonorant clusters, 
anaptyctic outputs are judged as sounding more like the input than prothetic outputs; while, the opposite is true for the input sibilant + stop clusters. Drawing on these experimental results, she develops a constraint-based analysis of vowel epenthesis in relation to wordinitial consonant clusters in which the notion of auditory similarity to input plays a crucial role.

In her constraint-based analysis, Fleischhacker proposes a series of perceptually grounded positional constraints, an extension of the faithfulness constraint DEP-VOWEL (McCarthy \& Prince 1995), to differentially regulate vowel insertion between specific segment types. She presents a schematic typological summary and proposes a continuum of /S/-initial cluster types along which languages are placed according to whether or not they allow for prothesis to resolve an onset cluster (Fleischhacker 2001). We will get back to this typological continuum in detail in Section 4.2 when discussing the exceptional cases of /S/-initial cluster adaptations in Persian.

Gouskova (2001) argues that the split pattern in epenthesis in loanword adaptation is an effect of SYLLABLE CONTACT; i.e. the preference for sonority to fall across a syllable boundary (Murray \& Vennemann 1983, Vennemann 1988). She asserts that "while the epenthesis itself is driven by the prohibition on clusters, its site is determined by SYLLABLE CONTACT". Presenting new evidence from Russian loanwords borrowed into Kirgiz, she maintains that the purported limitation of the split pattern to s-obstruent clusters is an artefact of the source of the loanwords, English and French - these clusters are the only falling sonority clusters in English and French, the chief loanword sources for the languages discussed in her study. In Gouskova's view, the resistance of s-initial clusters to internal epenthesis arises from their sonority properties and from independently needed constraints rather than from a difference in structure or special perceptual properties (Gouskova 2001). 
In a related study on loanwords in Persian, Kambuziya \& Hashemi (2011) analysed some of the phonological rules of Russian loanword adaptation in Persian, within an Optimality-theoretic framework. In this study, by gathering about fifty current Russian loanwords, the authors analysed some phonological processes occurring in Russian loanwords in Persian, including processes used in resolving foreign syllable structures which are illicit in Persian. Regarding the split pattern of vowel epenthesis in loanwords, they refer to Broselow (1999) in arguing that when CVC languages borrow loanwords with complex onsets, they often treat s-obstruent clusters differently from all others. In s-obstruent clusters, a vowel is inserted at the edge; while in rising sonority clusters, a vowel is inserted between the two consonants of the onset. They argue to account for this difference in behaviour of the s-obstruent clusters by using context-specific constraints of the type DEP-[e]/S_C (Fleischhacker 2001), without, however, really modifying the context S_C, which seems to uniformly account for the Russian data under discussion - in which case the use of SCL would possibly provide a more uniform explanation. The authors argue that prothesis is not allowed for consonant clusters which have rising sonority; without, however, referring to the exceptional cases like 'snack' [?es.nac] or 'slang' [?es.lanj]—which are, of course, not included in their Russian data - which have rising sonority and still undergo prothesis. We will return to these exceptional cases in Section 4.2.

While not particularly focused on established loanwords, Jabbari et al. (2012) in their study investigated the different strategies that Persian learners of English employ to deal with initial consonant clusters. While referring to vowel epenthesis as the most widespread repair strategy, they examined the two approaches that seek to explain the varying nature of the epenthetic site. They argue that, the first approach - the one based on the sonority profile of the segments- 
does not offer a plausible account, in particular with respect to the repair of s-sonorant clusters. The second approach, which the authors favour, is based on Fleischhacker's $(2001,2005)$ analysis and argues that the epenthetic site is based on maximal perceptual similarity between input and output. An experiment with Persian listeners is reported which is argued to confirm the crucial role of perceptual similarity. The researchers employed this approach in an Optimalitytheoretic framework, which is seen to make the correct predictions for the realisation of the different types of clusters. One could argue, however, that even in the second approach which is based on Fleischhacker's analysis, and in her typological continuum of /S/initial cluster types along which languages are placed, the sonority profile of the segments is somehow reflected, as the /SR/ (sibilantsonorant) clusters are ordered roughly by decreasing sonority of the second segment, i.e. the sonorant (Fleischhacker 2001). This typological continuum with particular reference to the place of Persian on it will be taken up in Section 4.2 when discussing the exceptional cases of /SN/ and /SL/ clusters adaptation.

In a more recent study, Krämer (2014) presents the results of a nonce-word production experiment with nine native speakers that tests rising and falling sonority clusters. While some speakers are reported to display prothesis only for $/ \mathrm{sC} /$ clusters, others prefer prothesis as well for clusters in which the first segment is a nasal homorganic with the following consonant and yet other subjects use prothesis with all nasal-initial clusters or all sonorant-initial clusters. Krämer attributes this split pattern to an interaction of the constraint against stringinternal insertion, namely CONTIGUITY, with constraints demanding the licensing of features by onsets, i.e. CODA CONDITION, which are defined language-specifically and allow only a restricted set of consonants in the syllable coda. He argues that prothesis is the default 
Amir Ghorbanpour, Aliyeh K. Z. Kambuziya, Mohammad Dabir-Moghaddam \& Ferdows Agha-Golzadeh 105

strategy to avoid complex onsets, while anaptyxis is triggered by the CODA CONDITION. Krämer further adds that since the CODA CONDITION (or any specific onset faithfulness) otherwise does not play a role in the Persian phonotactics - since, as Krämer correctly observes, Persian allows all sorts of consonants in coda position ${ }^{2}$-, it can be concluded that the CODA CONDITION is present in the grammar of Persian even though it cannot have been learned from primary linguistic data in first language acquisition. As an example, he asserts that the initial consonant in 'snack' does not violate CODA CONDITION when brought into coda position, and CONTIGUITY decides for prothesis: [?es.nac]. Whereas, the initial consonant in 'flash' violates CODA CONDITION if in coda position, because it has a marked place of articulation, and thus, anaptyxis is preferred, in violation of CONTIGUITY: [fe.laf]. However, this analysis fails to account for the examples like 'Sri Lanka' or 'shrine' — not a loanword, but when pronounced by Persian speakers as a foreign word-, where the initial consonant has the same unmarked place of articulation (coronal) as /s/ in 'snack', and they still undergo anaptyxis: [se.ri.lan.ka], [Je.rajn]. Such examples will be looked at in more detail in Section 4.2.

There are other studies as well which have investigated loanword adaptation in Persian, including, among others, Farazandehpour \& Kambuziya's (2014) study on German loanword adaptation in Persian, Hashemi et al.'s (2014) work on Arabic loanword adaptation, and Kambuziya \& Mirzaei Hosseinzadeh's (2014) study on the vowel

\footnotetext{
2 Samareh (1999: 113) lists only three restrictions on the appearance of consonants in the coda position in Persian, which even in these cases their exclusion depends on the preceding vowel; these include 1) the appearance of $/ \mathrm{y} / \mathrm{after}$ the vowels $/ \mathrm{o} /$ and /e/, hence excluding /-oj/ and /-ej/ sequences; 2) the appearance of $/ \mathrm{v} /$ after the vowel $/ \mathrm{u} /$, hence excluding the $/$-uv/ sequence; and 3 ) the appearance of $/ 3 /$ after the vowel /i/, hence excluding /-iz/. Other than these three cases, any consonant can appear as a coda after any vowel (ibid.: 114).
} 
adaptation of the English loanwords in Persian; however, they have been mainly focused on segmental adaptation and not in particular on any split epenthesis pattern in syllabic adaptation.

Following this brief review of the previous studies and analyses of the split pattern in onset cluster resolution, this study looks at the process of loanword syllabic adaptation in a set of tetrasyllabic words in Persian, and the strategies adopted by the language to modify the ill-formed structures in order to meet the syllabic requirements of Persian. These processes are studied within an Optimality-theoretic framework. Based on the data under discussion, we will argue that an analysis based on the effect of the SYLLABLE CONTACT provides a better explanation for the split pattern of vowel epenthesis in loanword syllabic adaptation in Persian and it uniformly holds true for the dictionary-derived data in the present study. For the exceptional cases of /SN/ (sibilant-nasal) and /SL/ (sibilant-liquid) clusters-which are not attested in our data, but still present and often referred to in the literature-we will propose the addition of two positional, contextsensitive faithfulness constraints of the DEP-V/X_Y family (Fleischhacker 2001) to our set of universal constraints to account for all the possible cases of loanword syllabic adaptation in Persian.

\section{Data and Method}

The data in this study include the set of tetrasyllabic nativised loanwords in Persian which have been re-syllabified in their phonetic realisations due to having consonant clusters in onset positions. However, this choice does not imply that there is anything special about this set of words - i.e. tetrasyllables — in terms of their syllable structure and adaptation; rather, the reason is only that this study is part of a larger project which examines the phonotactic constraints of 
tetrasyllables in Persian. The words were extracted from a contemporary Persian dictionary (Moshiri 2009), and sorted in a Microsoft Office Excel worksheet with all their etymological, phonological and morphological information subsequently added. Out of the whole set of 812 tetrasyllabic loanwords, a total of 67 words - of English and French origin — containing onset clusters, and hence undergoing resyllabification in their phonetic realisations, were then identified. This number refers to the actual entries in the aforementioned dictionary, and obviously, it does not include many of the proper nouns and inflected forms. The types and frequency of the attested onset clusters together with examples of their surface realisations in Persian are given in Table 2 below. The nativised pronunciation of the loanwords has been based on the transcriptions provided in the aforementioned Persian dictionary and also the linguistic intuition of the authors as native speakers of Persian. Hence, the pronunciations given in examples as surface realisations are argued to represent the most common pronunciations of these loanwords as spoken by Persian speakers.

It needs to be noted that the details surrounding some segmental adaptations to fit the sound system and phoneme inventory of Persian do not concern the arguments made in the present study and are hence not discussed here. Regarding the quality of the epenthetic vowel, however, as can be seen in the examples in Table 2 and throughout the paper, the inserted vowel in nearly all loanwords in our data is the close-mid front vowel [e] by default, and only in cases where the following syllable includes a non-low back vowel, the epenthetic vowel assimilates to it and is realised as [o]; for example, in [ko.ro.ko.dil] 'crocodile'. 
Table 2. Attested Onset Clusters in Borrowed Loanwords with Examples

\begin{tabular}{|c|c|c|c|}
\hline Onset Cluster & Occurrence & Example & Surface Realisation \\
\hline $\mathrm{gr}$ & 11 & gramophone & [je.ra.ma.fon] \\
\hline $\mathrm{gl}$ & 2 & glycerine & [je.li.si.rin] \\
\hline $\mathrm{kr}$ & 7 & crocodile & [ko.ro.ko.dil] \\
\hline $\mathrm{kl}$ & 4 & chlorophyll & [ko.lo.ro.fil] \\
\hline $\mathrm{pr}$ & 12 & president & [pe.re.zi.dent] \\
\hline $\mathrm{pl}$ & 3 & plastic & [pe.las.ti.ci] \\
\hline $\mathrm{tr}$ & 7 & tragedy & [te.ra.3e.di] \\
\hline $\mathrm{dr}$ & 5 & dramatic & [de.ra.ma.tic] \\
\hline $\mathrm{fr}$ & 4 & fraction & [fe.rac.si.jon] \\
\hline $\mathrm{st}$ & 8 & stadium & [es.ta.di.jom] \\
\hline $\mathrm{sk}$ & 3 & tele ski & [te.le. Pes.ci] \\
\hline $\mathrm{sp}$ & 1 & spaghetti & [?es.pa.Je.ti] \\
\hline
\end{tabular}

The data are referred to in the course of analysis as examples and as supporting evidence for the claims made in the study.

As already pointed out, we adopt a constraint-based Optimalitytheoretic framework in our analyses (Prince \& Smolensky 1993/2004, McCarthy 2008). The constraints used in the study are each defined in the relevant sections when first introduced and used in the analyses and in the tableaux. 
Amir Ghorbanpour, Aliyeh K. Z. Kambuziya, Mohammad Dabir-Moghaddam \& Ferdows Agha-Golzadeh 109

\section{Analysis}

\subsection{Onset Cluster Resolution in the Data}

Table 2 in Section 3 shows all the attested onset clusters in our data which are re-syllabified in their phonetic realisations in Persian to meet the syllable structure requirements of the target language. As already referred to in the introduction, this syllabic adaptation of onset consonant clusters in Persian takes three different forms as sketched above in (1) to (3) and reproduced here again in (4) to (6), for the ease of reference:

(4) Onset cluster resolution: re-syllabification without epenthesis [de.moc.ra.si] 'democracy' [bu.roc.ra.si] 'bureaucracy'

[bi.jof.ra.fi] 'biography'

[te.lej.ra.fi] 'telegraphic'

(5) Onset cluster resolution: anaptyxis [te.ra.ze.di] 'tragedy' [pe.re.zi.dent] 'president' [te.ran.zis.tor] 'transistor' [po.ro.te.Pin] 'protein' [de.ra.ma.tic] 'dramatic' [po.ro.fe.sor] 'professor' [je.ra.ma.fon] 'gramophone' [po.ro.to.kol] 'protocol' [pe.las.ti.ci] 'plastic' [ko.ro.ko.dil] 'crocodile'

(6) Onset cluster resolution: prothesis [Pes.ta.di.jom] 'stadium' [Pes.to.di.jo] 'studio' [Pes.pa.je.ti] 'spaghetti' [Pes.ta.lac.tit] 'stalactite' 
To begin with, as briefly discussed above in Section 2.1 , the syllable structure of Persian in phonetic realisation is generally said to be $\mathrm{CV}(\mathrm{C})(\mathrm{C})$; that is, any syllable in its surface form contains an obligatory onset consonant, an obligatory vowel as nucleus, and an optional coda consisting of one or two consonants (Windfuhr 1997, Haghshenas 1999, Samareh 1999, Kambuziya 2007, inter alia). Therefore, Persian does not allow syllables without an onset consonant and neither does it allow complex onsets-i.e. consonant clusters in the onset position. In Optimality-theoretic terms, this means that two markedness constraints on basic syllable structure are never violated in Persian and are thus undominated. These two markedness constraints are ONSET, which requires syllables to have onsets, and *COMPLEXONSET, which bans syllables from having complex onsets. The two constraints are given and formally defined below:

(7) ONSET (Prince \& Smolensky 1993/2004, McCarthy 2008: 225) Assign one violation mark for every onsetless syllable.

(8) *COMPLEX-ONSET (*COMP-ONS) (Prince \& Smolensky 1993/2004, McCarthy 2008: 224)

Assign one violation mark for every tautosyllabic cluster in the onset position.

However, in order for the above-mentioned markedness constraints to be inviolable in the language, it means that they need to be ranked higher relative to the faithfulness constraints which ban any differences between inputs and outputs. These two anti-deletion and anti-epenthesis faithfulness constraints are given below: 
(9) MAX-IO (McCarthy \& Prince 1995, 1999, McCarthy 2008: 37) Assign one violation mark for every input segment that does not have an output correspondent. (No deletion)

(10) DEP-IO (McCarthy \& Prince 1995, 1999, McCarthy 2008: 37) Assign one violation mark for every output segment that does not have an input correspondent. (No epenthesis)

Adding the No-CoDA constraint defined in (11) to the list- which is ranked low enough in Persian to allow surface structures to have codas (as referred to above, Persian syllables can have an optional coda consisting of one or two consonants) - the following ranking of the interacting constraints in (12) accounts for a scenario where a cluster is broken up through re-syllabification without epenthesis; that is, a case in which an onset cluster is placed word-medially subsequent to an open syllable, and the first segment of the cluster moves to the empty coda position of the preceding syllable.

(11) No-CODA (McCarthy 2008: 225)

Assign one violation mark for every coda consonant.

(12) Onset cluster resolution: re-syllabification without epenthesis ONSET, *COMP-ONS $\gg$ MAX-IO $\gg$ DEP-IO $\gg$ NO-CODA

Tableau 1 illustrates the evaluation of the input (French) noun 'démocratie' based on the ranking of constraints given in (12): 
Tableau 1. Evaluation Tableau for the Input 'démocratie'/deməkrasi/ (from French) $)^{3}$

\begin{tabular}{|c|c|c|c|c|c|}
\hline $\begin{array}{c}\text { démocratie } \\
\text { /demokrasi/ }\end{array}$ & ONSET & $\begin{array}{c}\text { COMP- } \\
\text { ONS }\end{array}$ & MAX-IO & DEP-IO & $\begin{array}{c}\text { NO- } \\
\text { CODA }\end{array}$ \\
\hline de.moc.ra.si & & & & & $*$ \\
\hline de.mo.ce.ra.si & & & & $* !$ & \\
\hline de.mo.ec.ra.si & $* !$ & & & $*$ & $*$ \\
\hline de.mo.Pec.ra.si & & & & $* * !$ & $*$ \\
\hline de.mo.cra.si & & $* !$ & & & \\
\hline de.mo.ra.si & & & $* !$ & & \\
\hline
\end{tabular}

In the above tableau, no direct ranking argument can be formed between the two markedness constraints ONSET and *COMPLEXONSET - and hence the dotted line-, as the two constraints are equally ranked highest and remain unviolated in Persian. Moreover, although there is no direct ranking argument in this particular example to position MAX-IO higher than DEP-IO, the reason for placing MAXIO higher here is that in Persian an onset cluster is generally avoided through the insertion, rather than deletion, of a segment - as we will see in the next section covering cases of epenthesis.

Turning now to the other two groups of words in which the onset cluster, being placed word-initially, is resolved through the insertion of an epenthetic vowel in a split pattern - see (5) and (6) - , we observe that, in line with Gouskova's (2001) argument, this split pattern is an effect of the SCL; i.e. the preference for sonority to fall

${ }^{3}$ In OT tableaux, cells that are shaded are those that have no effect on the outcome because the competition has already been decided by higher-ranking constraints (McCarthy 2008: 45). 
across a syllable boundary (Murray \& Vennemann 1983, Vennemann 1988), along a sonority scale like the rather simplified one given below (Kager 1999: 215):

\section{(13) Sonority scale plosives $<$ fricatives $<$ nasals $<$ liquids $<$ vocoids}

In an anaptyxis scenario, the cluster-internal epenthesis is argued to be triggered by the need to satisfy SCL. As the examples in (5) and in Table 2 suggest, in all cases of anaptyxis in our data, the onset cluster segments have a sequence of rising sonority which is not preferred in a syllable boundary position according to SCL. Therefore, to satisfy SCL, an epenthetic vowel is inserted between the two segments (e.g. [te.ra.ze.di] 'tragedy'), rather than before the segments (*[et.ra.ze.di]), to avoid an undesired syllable boundary.

In an edge epenthesis in a prothesis scenario, however, in all the examples in our data the onset cluster segments display a sequence of falling sonority. This pattern uniformly holds true at least for the set of data under discussion. In these cases, since the SCL would be fully satisfied in a syllable boundary position, the epenthesis occurs clusterinitially; here the process is argued to be driven by the CONTIGUITY constraint which bans any morpheme-internal epenthesis in the output, and is hence violated when a segment is epenthesised medially (McCarthy 2008: 174, 197). The two conflicting constraints active and decisive in these two scenarios are given and defined below:

\section{(14) Syllable CONTACT (SYLL-CON)}

(Gouskova 2004, McCarthy 2008: 229) Assign one violation mark for every syllable boundary with a rising sonority. 
(15) Contiguity (CONTIG)

(Gouskova 2003, McCarthy 2008: 174, 197) Assign one violation mark for every morpheme-internal epenthesis.

Based on the two patterns of anaptyxis and prothesis - as seen in (5) and (6) - , it can be argued that, CONTIGUITY is observed only to the extent it does not violate the SYLL-CON; therefore, in Optimalitytheoretic terms this means that CONTIGUITY should be placed lower than SYLL-CON in the constraint ranking.

Since in Persian ONSET is unviolated and a glottal stop [?] is said to be inserted in any onsetless syllable in surface realisation, we also need to parameterise the faithfulness constraint DEP-IO to cover cases of vowel and consonant epenthesis separately; that is, to indicate in Optimality-theoretic terms that in Persian vowel and consonant epentheses are tolerated to different degrees. The two vowel- and consonant-specific DEP constraints are then given and defined below:

(16) DEP-V (McCarthy 2008: 49, 250)

Assign one violation mark for every output vowel segment that does not have an input correspondent. (No vowel epenthesis)

(17) DEP-C (McCarthy 2008: 250)

Assign one violation mark for every output consonant segment that does not have an input correspondent. (No consonant epenthesis)

The consonant-specific DEP-C should be ranked lower than CONTIGUITY to allow for the insertion of an extra segment [?] wordinitially in a prothesis scenario, as is the case with [?es.ta.di.jom] 
'stadium' (see Tableau 2 below). The vowel-specific DEP-V, on the other hand, is ranked higher than SYLL-CON, to warrant that SYLLCON does not trigger unnecessary cases of vowel epenthesis where a cluster can be resolved without the need for the insertion of an epenthetic vowel, as is the case with the examples in (4) which involve re-syllabification without epenthesis (also see Tableau 4 below). In other words, satisfying SYLL-CON in Persian is only relative and dependent on the higher-ranked faithfulness constraint DEP-V.

Tableau 2 below illustrates the evaluation of the input word 'stadium', with the new constraints added and ranked accordingly.

Tableau 2. Evaluation Tableau for the Input 'stadium'/sterdıəm/ (from English)

\begin{tabular}{|c|c|c|c|c|c|c|c|}
\hline $\begin{array}{c}\text { stadium } \\
\text { /steIdiəm/ }\end{array}$ & ONSET & $\begin{array}{c}* \text { COMP- } \\
\text { ONS }\end{array}$ & $\begin{array}{c}\text { MAX- } \\
\text { IO }\end{array}$ & $\begin{array}{c}\text { DEP- } \\
\text { V }\end{array}$ & $\begin{array}{c}\text { SYLL- } \\
\text { CON }\end{array}$ & CONTIG & $\begin{array}{c}\text { DEP } \\
\text {-C }\end{array}$ \\
\hline Pes.ta.di.jom & & & & $*$ & & $*$ & $* *$ \\
\hline se.ta.di.jom & & & & $*$ & & $* * !$ & $*$ \\
\hline es.ta.di.jom & $* !$ & & & $*$ & & $*$ & $*$ \\
\hline sta.di.jom & & $* !$ & & & & $*$ & $*$ \\
\hline ta.di.jom & & & $* !$ & & & $*$ & $*$ \\
\hline
\end{tabular}

In Tableau 3, the input (French) word 'tragédie', which involves a case of anaptyxis, is evaluated based on the same ranking of constraints given in Tableau 2 above. Here, as can be seen, the SYLLCON, through being ranked higher than CONTIGUITY, triggers the insertion of an epenthetic vowel between the two segments to avoid an undesired syllable boundary. 
Tableau 3. Evaluation Tableau for the Input 'tragédie' /trazedi/ (from French)

\begin{tabular}{|c|c|c|c|c|c|c|c|}
\hline $\begin{array}{c}\text { tragédie } \\
\text { /trazedi/ }\end{array}$ & ONSET & $\begin{array}{c}* \text { COMP- } \\
\text { ONS }\end{array}$ & $\begin{array}{c}\text { MAX- } \\
\text { IO }\end{array}$ & $\begin{array}{c}\text { DEP- } \\
\text { V }\end{array}$ & $\begin{array}{c}\text { SYLL- } \\
\text { CON }\end{array}$ & CONTIG & $\begin{array}{c}\text { DEP } \\
\text {-C }\end{array}$ \\
\hline te.ra.ze.di & & & & $*$ & & $*$ & \\
\hline et.ra.ze.di & $* !$ & & & $*$ & $*$ & & \\
\hline Pet.ra.ze.di & & & & $*$ & $* !$ & & $*$ \\
\hline tra.3e.di & & $* !$ & & & & & \\
\hline ta.ze.di & & & $* !$ & & & & \\
\hline
\end{tabular}

Tableau 4 revisits the evaluation of the input word 'démocratie' with the whole set of constraints added to the tableau, to show how unnecessary vowel epenthesis is avoided by placing DEP-V higher than SYLL-CON.

Tableau 4. Evaluation Tableau for the Input 'démocratie'/demokrasi/ (Revisited)

\begin{tabular}{|c|c|c|c|c|c|c|c|}
\hline $\begin{array}{c}\text { démocratie } \\
\text { /demokrasi/ }\end{array}$ & ONSET & $\begin{array}{c}* \text { COMP- } \\
\text { ONS }\end{array}$ & $\begin{array}{c}\text { MAX- } \\
\text { IO }\end{array}$ & $\begin{array}{c}\text { DEP- } \\
\text { V }\end{array}$ & $\begin{array}{c}\text { SYLL- } \\
\text { CON }\end{array}$ & CONTIG & $\begin{array}{c}\text { DEP } \\
\text { de.moc.ra.si }\end{array}$ \\
\hline de.mo.ce.ra.si & & & & & $*$ & & \\
\hline de.mo.ec.ra.si & $* !$ & & & $*$ & $*$ & & \\
\hline de.mo.Pec.ra.si & & & & $* !$ & $*$ & & $*$ \\
\hline de.mo.cra.si & & $* !$ & & & & & \\
\hline de.mo.ra.si & & & $* !$ & & & & \\
\hline
\end{tabular}


Amir Ghorbanpour, Aliyeh K. Z. Kambuziya, Mohammad Dabir-Moghaddam \& Ferdows Agha-Golzadeh 117

Finally, to wrap up this section, an interesting example of a loanword which displays both processes of anaptyxis and prothesis within a single string is the input word 'drugstore' which is syllabified as [de.ra.jes.tor] in Persian. The evaluation tableau for this syllabification with the same constraint set and ranking is illustrated below in Tableau 5.

Tableau 5. Evaluation Tableau for the Input 'drugstore'/drıgsto(r)/ (from English)

\begin{tabular}{|c|c|c|c|c|c|c|c|}
\hline $\begin{array}{c}\text { drugstore } \\
\text { /drıgsto(r)/ }\end{array}$ & ONSET & $\begin{array}{c}\text { COMP- } \\
\text { ONS }\end{array}$ & $\begin{array}{c}\text { MAX- } \\
\text { IO }\end{array}$ & $\begin{array}{c}\text { DEP- } \\
\text { V }\end{array}$ & $\begin{array}{c}\text { SYLL- } \\
\text { CON }\end{array}$ & CONTIG & $\begin{array}{c}\text { DEP } \\
\text {-C }\end{array}$ \\
\hline de.ra.Jes.tor & & & & $* *$ & & $*$ & $*$ \\
\hline Ped.ra.Jes.tor & & & & $* *$ & $* !$ & & $*$ \\
\hline de.raj.se.tor & & & & $* *$ & $* !$ & $*$ & \\
\hline dra.Jes.tor & & $* !$ & & $*$ & & & \\
\hline de.raj.stor & & $* !$ & & $*$ & $*$ & $*$ & \\
\hline de.raj.sor & & & $* !$ & $*$ & $*$ & $*$ & \\
\hline
\end{tabular}

To sum up so far, the overall ranking of the relevant constraints on loanword syllabic adaptation in Persian is as follows:

(18) Overall ranking of constraints in onset cluster resolution: anaptyxis and prothesis

ONSET, *COMPLEX-ONSET $\gg$ MAX-IO $\gg$ DEP-V $\gg$
SYLL-CON $\gg$ CONTIGUITY $\gg$ DEP-C $\gg$ NO-CODA


The overall ranking given in (18) uniformly accounts for all cases of onset cluster resolution in the set of data in our study; that is, the three scenarios of anaptyxis, prothesis, and re-syllabification without epenthesis.

\subsection{The Case of /SN/ and /SL/ Clusters}

In this section, we will discuss the special cases of /SN/ (sibilantnasal) and /SL/ (sibilant-liquid) clusters, which are not attested in our set of data, but still present - whether as established loanwords or as nativised pronunciation of foreign words - and frequently referred to in the literature. In Persian, in three special cases of /S/-initial clusters which display a sequence of rising sonority, namely the $/ \mathrm{Sn} /, / \mathrm{Sm} /$ and /S1/ clusters, the vowel is inserted cluster-initially through prothesis which goes counter the general argument made earlier in favour of the effect of the SYLLABLE CONTACT. In fact, these three cases are exceptions to the set of universal constraints ranked in (18) above. Examples of /SN/ clusters which are uniformly resolved by prothesis, contrary to the SYLLABLE CONTACT, are shown in (19) below. The examples in (20), however, indicate that regarding the /SL/ (sibilantliquid) clusters, this pattern of epenthesis is not uniform and it is only in the /S1/-i.e. sibilant + lateral liquid-environment that the epenthetic site goes counter to the SYLLABLE CONTACT. Hence, there are only three clusters, namely $/ \mathrm{Sn} /, / \mathrm{Sm} /$ and $/ \mathrm{Sl} /$ which count as exceptions to the generalisation made in (18) regarding the satisfaction of SYLL-CON in loanword syllabic adaption in Persian. 
(19) Onset cluster resolution: prothesis in /SN/ environment

[Pes.nac] 'snack'

[Pes.ni.cer] 'sneaker'

[?es.moc] 'smoke'

[Pes.mart] 'smart'

[?eJ.mit] 'Schmitt'

[PeJ.naj.der] 'Schneider'

(20) Onset cluster resolution: prothesis/anaptyxis split pattern in /SL/ environment

$\begin{array}{ll}\text { [?es.lanj] } & \text { 'slang' } \\ \text { [?es.lip] } & \text { 'sleep' } \\ \text { [se.ri.lan.ka] } & \text { 'Sri Lanka'4 }\end{array}$

Fleischhacker (2001) puts forward a formal analysis in which context-specific DEP constraints regulate the location of epenthetic vowels in languages which display anaptyxis-prothesis asymmetries. She argues that "such patterns reflect an epenthesis strategy in which the site of epenthesis is chosen to maximise perceptual similarity between input and output." She proposes a continuum of /S/-initial cluster types along which languages are placed according to whether they allow for prothesis to resolve an onset cluster. This continuum is reproduced below with particular reference to the place of Persian on it.

4 The onset cluster / $\mathrm{Sr} /$ is rarely seen in loanwords borrowed into Persian and this example seems to be the only one attested and frequently cited in the literature (Fleischhacker 2001, Modarresi 2006). Other possible examples could be a few proper nouns as well; e.g. [Je.ro.der] 'Schroeder' (Shademan, as cited in Fleischhacker 2001). Modarresi Ghavami attributes this different pattern of prothesis vs. anaptyxis in $/ \mathrm{SL} /$ clusters to the different articulatory and acoustical features of the liquid sounds $/ \mathrm{r} /$ and $/ 1 /$; in that $/ \mathrm{r} /$ behaves more like vowels in articulatory and acoustical terms, whereas $/ 1 /$ is more like consonants with respect to these features. 
(21) Vowel epenthesis pattern in languages with respect to onset clusters, and the place of Persian on the continuum (Fleischhacker 2001)

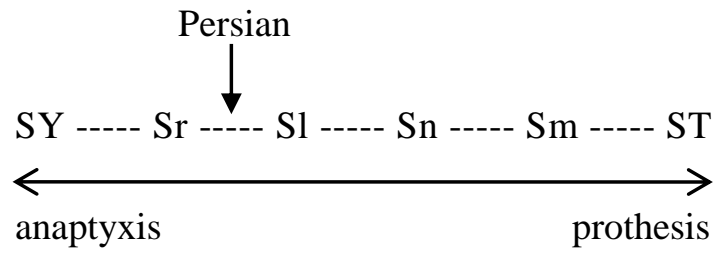

To account for the exceptional cases of rising sonority clusters referred to above $-/ \mathrm{Sn} /, / \mathrm{Sm} /$ and $/ \mathrm{Sl} /-,{ }^{5}$ we need to add two positional, context-sensitive faithfulness constraints of the DEPV/X_Y family (Fleischhacker 2001) to our set of universal constraints we have had so far. The two positional constraints are given below:

(22) DEP-V/S_N (adapted from Fleischhacker 2001)

Assign one violation mark for every output vowel between a sibilant-nasal sequence that does not have an input correspondent. (No vowel epenthesis in /S_N/ environment)

${ }^{5}$ One might raise the possibility of an alternative generalisation implying that $/ \mathrm{S} / \mathrm{-}$ initial onset clusters behave differently as a set; they all opt for prothesis, while those beginning with stop consonants opt for anaptyxis. In this view, the only exception would be $/ \mathrm{Sr} /$ clusters, which are rare in English too. However, this is not the case, as the differential pattern of epenthesis in / $\mathrm{S} /$-initial clusters is not limited to $/ \mathrm{Sr} /$ clusters. Rather, the sibilant-glide sequences are also resolved through anaptyxis; examples include 'switch' [su.witf]/ (alternatively [su.Pit]]), swift [su.wift]

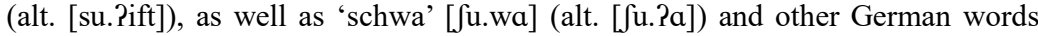
beginning with 'schw-' sequence (the emergence of a different epenthetic vowel in these words - i.e. [u] - is because of assimilation to the corresponding glide $[\mathrm{w}]$ ). 
(23) DEP-V/S_l (adapted from Fleischhacker 2001)

Assign one violation mark for every output vowel between a sibilant-liquid(lateral) sequence that does not have an input correspondent. (No vowel epenthesis in /S_1/ environment)

In order to count as exceptions to the SCL, the two new constraints should be ranked higher than SYLL-CON in the constraints set. Also, as more specific cases of the faithfulness constraint DEP-V, these positional constraints should be ranked higher than their more general equivalent DEP-V in order to have any effect at all on evaluating the optimal output.

Tableau 6 below illustrates the evaluation of the input word 'snack' against the set of constraints ranked accordingly. In this tableau, DEPV/S_N is ranked higher than both DEP-V and SYLL-CON to give the optimal output as realised in Persian.

Tableau 6. Evaluation Tableau for the Input 'snack'/snak/ (from English)

\begin{tabular}{|c|c|c|c|c|c|c|c|}
\hline $\begin{array}{c}\text { snack } \\
\text { /snak/ }\end{array}$ & ONSET & $\begin{array}{c}* \text { COMP- } \\
\text { ONS }\end{array}$ & $\begin{array}{c}\text { MAX- } \\
\text { IO }\end{array}$ & $\begin{array}{c}\text { DEP-V/ } \\
\text { S_N }\end{array}$ & $\begin{array}{c}\text { DEP- } \\
\text { V }\end{array}$ & $\begin{array}{c}\text { SYLL- } \\
\text { CON }\end{array}$ & CONTIG \\
\hline Pes.nac & & & & & $*$ & $*$ & \\
\hline es.nac & $* !$ & & & & $*$ & $*$ & \\
\hline se.nac & & & & $* !$ & $*$ & & $*$ \\
\hline snac & & $* !$ & & & & & \\
\hline nac & & & $* !$ & & & & \\
\hline
\end{tabular}

In the same vein, Tableau 7 illustrates the evaluation of the input word 'slang' in which DEP-V/S_l decides on the optimal output [?es.lanf]. 
Tableau 7. Evaluation Tableau for the Input 'slang'/slay/(from English)

\begin{tabular}{|l|c|c|c|c|c|c|c|}
\hline $\begin{array}{c}\text { slang } \\
\text { /slay/ }\end{array}$ & ONSET & $\begin{array}{c}* \text { COMP- } \\
\text { ONS }\end{array}$ & $\begin{array}{c}\text { MAX- } \\
\text { IO }\end{array}$ & $\begin{array}{c}\text { DEP-V/ } \\
\text { S_1 }\end{array}$ & DEP-V & $\begin{array}{c}\text { SYLL- } \\
\text { CON }\end{array}$ & CONTIG \\
\hline Pes.lanf & & & & & $*$ & $*$ & \\
\hline es.lanf & $* !$ & & & & $*$ & $*$ & \\
\hline se.lanf & & & & $* !$ & $*$ & & $*$ \\
\hline slanf & & $* !$ & & & & & \\
\hline lanf & & & $* !$ & & & & \\
\hline
\end{tabular}

Adding the two positional, language-specific constraints to our set of universal constraints in (18), we will have the following ranking of constraints active and decisive for all possible cases of loanword syllabic adaptation in Persian:

(24) Overall ranking of constraints in onset cluster resolution: anaptyxis and prothesis (final ranking)

ONSET, *COMPLEX-ONSET $\gg$ MAX-IO 》 DEP-V/S_1, DEP-V/S_N $\gg$ DEP-V $\gg$ SYLL-CON $\gg$ CONTIGUITY

\section{DEP-C $\gg$ NO-CODA}

In the above ranking, there is no direct ranking argument to place any of the positional constraints DEP-V/S_l or DEP-V/S_N higher than the other, since the two constraints do not interact with each other, and hence the comma between them. 
Amir Ghorbanpour, Aliyeh K. Z. Kambuziya, Mohammad Dabir-Moghaddam \& Ferdows Agha-Golzadeh 123

\section{Conclusion}

In this paper, we examined the process of loanword syllabic adaptation in tetrasyllabic words in Persian, within an Optimalitytheoretic framework. We argued that an analysis based on the effect of the SYLLABLE CONTACT provides a better explanation for the split pattern of vowel epenthesis in loanword adaptation in Persian and it uniformly holds true at least for the data in the present study. For the exceptional cases of /SN/ and /SL/ clusters - which are not attested in our data, but still present and often referred to in the literature - we proposed the addition of two positional, context-sensitive faithfulness constraints of the DEP-V/X_Y family (Fleischhacker 2001) to the set of the universal constraints. It should be noted that, as already argued in Section 2.2, even in Fleischhacker's analysis, and in her typological continuum of /S/-initial cluster types along which languages are placed according to whether they allow for prothesis to resolve an onset cluster, the sonority profile of the segments is somehow reflected, as the /SR/ (sibilant-sonorant) clusters are ordered roughly by decreasing sonority of the second segment, i.e. the sonorant (Fleischhacker 2001). It can be argued that, while Fleischhacker's analysis accounts for exceptional cases which are defined languagespecifically along the continuum given in (21), the general tendency of the split pattern is clearly in line with a SYLLABLE CONTACT account - as the data under discussion in this study suggest.

The overall ranking of constraints given in (24) is argued to account for all the possible cases of loanword syllabic adaptation in Persian, whether included in the data in the present study or not. Making use of the universal constraints SYLL-CON and CONTIGUITY makes the present analysis more uniform and comparable cross-linguistically and, at the same time, the exceptional cases of /SN/ and /S1/ cluster 
124 Loanword Syllable Adaptation in Persian: An Optimality-Theoretic Account

resolution which go counter to SYLL-CON have been accounted for by the addition of two positional, language-specific constraints DEPV/S_N and DEP-V/S_1 which makes the constraint ranking in (24) a more generalisable one to encompass the whole set of possible loanword syllabic adaptations in Persian.

\title{
Abbreviations Used
}

\author{
C consonant \\ I input \\ L liquid \\ $\mathrm{N}$ nasal \\ O output \\ $\mathrm{R} \quad$ sonorant \\ S voiceless sibilant \\ SCL syllable contact law \\ $\mathrm{V}$ vowel
}


Amir Ghorbanpour, Aliyeh K. Z. Kambuziya, Mohammad Dabir-Moghaddam \& Ferdows Agha-Golzadeh 125

\section{References}

Broselow, E. 1992. Nonobvious Transfer: On Predicting Epenthesis Errors. In S. Gass \& L. Selinker (eds.), Language Transfer in Language Learning 71-86. Amsterdam: John Benjamins.

Broselow, E. 1999. Loanwords and Learnability. Handout of a Talk

Given at the University of Maryland, 3 December 1999.

Crystal, D. 2008. A Dictionary of Linguistics and Phonetics. 6th edition. Oxford: Blackwell.

Farazandehpour, F. \& A. Kambuziya. 2014. German Loanwords Adaptation in Persian: Optimality Approach. The International Journal of Humanities 20.4, 23-40.

Fleischhacker, H. 2001. Cluster-Dependent Epenthesis Asymmetries. UCLA Working Papers in Linguistics 7, 71-116.

Fleischhacker, H. 2005. Similarity in Phonology: Evidence from Reduplication and Loan Adaptation. Ph.D. Dissertation, University of California.

Ghorbanpour, A. et al. 2019. Hiatus Resolution in Persian: The Case of [f]-Epenthesis. Acta Linguistica Academica 66.1, 69-84.

Gouskova, M. 2001. Falling Sonority Onsets, Loanwords, and Syllable Contact. Chicago Linguistic Society 37.1, 175-185.

Gouskova, M. 2003. Deriving Economy: Syncope in Optimality Theory. Ph.D. Dissertation, University of Massachusetts Amherst. Gouskova, M. 2004. Relational Hierarchies in Optimality Theory: The Case of Syllable Contact. Phonology 21, 201-250.

Haghshenas, A. 1999. Avāshenāsi [Phonetics]. Tehran: Agah Press.

Hashemi, E. et al. 2014. Phonological Adaptation of Arabic Loan

Words in Persian: Consonants. International Journal and Humanities and Social Science 4.6, 225-236.

Jabbari, A. et al. 2012. The Adaptation of English Initial Clusters by 
Persian Learners. Journal of Teaching Language Skills 30.4, 59-76. Kager, R. 1999. Optimality Theory. Cambridge: CUP.

Kambuziya, A. 2007. Vājshenāsi: Ruykardhāa-ye ghā'ede-bonyād [Phonology: Rule-based approaches]. Tehran: Samt.

Kambuziya, A. \& E. Hashemi. 2011. Russian Loanword Adaptation in Persian: Optimal Approach. Iranian Journal of Applied Language Studies 3.1, 77-96.

Kambuziya, A. \& N. Mirzaei Hosseinzadeh. 2014. English Loanwords in Persian: Vowel Adaptation. Research on Humanities and Social Sciences 4.5, 1-15.

Kambuziya, A. et al. 2017. Vowel Shortening in Persian: A Phonological Analysis. Poznan Studies in Contemporary Linguistics 53.3, 373-397. Krämer, M. 2014. Vowel Epenthesis in Persian and the Coda Condition. Paper presented at the 12th Old World Conference in Phonology, Universitat de Barcelona, Barcelona.

McCarthy, J. 2008. Doing Optimality Theory: Applying Theory to Data. Oxford: Blackwell.

McCarthy, J. \& A. Prince. 1995. Faithfulness and Reduplicative Identity. In J. Beckman et al. (eds.), University of Massachusetts Occasional Papers in Linguistics 18, 249-384. Amherst, MA: GLSA.

McCarthy, J. \& A. Prince. 1999. Faithfulness and Identity in Prosodic Morphology. In R. Kager et al. (eds.), The Prosody-Morphology Interface 218-309. Cambridge: CUP.

Modarresi, G. 2006. Āghāze-ye hejā-ye Fārsi va rābete-ye ān bā farāyand-e ezāfe dar vāmvāzheha bar mabnāye nazariye behinegi [The Onset in Persian and Its Relation to the Process of Epenthesis in Loanwords Based on Optimality Theory]. Proceedings of the First Conference of the Linguistics Society of Iran. Tehran: Linguistics Society of Iran.

Moshiri, M. 2009. Persian Dictionary (Alphabetical-Analogical). 5th 
Amir Ghorbanpour, Aliyeh K. Z. Kambuziya, Mohammad Dabir-Moghaddam \& Ferdows Agha-Golzadeh 127

edition. Tehran: Soroush.

Murray, R. \& T. Vennemann. 1983. Sound Change and Syllable Structure in Germanic Phonology. Language 59, 514-528.

Prince, A. \& P. Smolensky. 1993/2004. Optimality Theory: Constraint Interaction in Generative Grammar. Oxford: Blackwell.

Samareh, Y. 1999. Avāshenāsi-ye zabān-e Fārsi: Avāhā va sākhte avā'i-ye hejā [The Phonetics of Persian: Sounds and Phonetic Structure of Syllable]. 2nd edition. Tehran: Iran University.

Singh, R. 1985. Prosodic Adaptation in Interphonology. Lingua 67, 269-282.

Vennemann, T. 1988. Preference Laws for Syllable Structure and the Explanation of Sound Change: With Special Reference to German, Germanic, Italian, and Latin. Berlin: Mouton de Gruyter.

Windfuhr, G. 1997. Persian Phonology. In A. Kaye (ed.), Phonologies of Asia and Africa 675-689. Winona Lake: Eisenbrauns. 